\title{
AUTHORS' RESPONSE (MARCH 14,2018) TO THE LETTER TO THE EDITOR CONCERNING THE PAPER "HISTOLOGICAL FINDINGS AND LUNG DUST ANALYSIS AS THE BASIS FOR OCCUPATIONAL DISEASE COMPENSATION IN ASBESTOS-RELATED LUNG CANCER IN GERMANY"
}

Dear Editor,

Thank you very much for the opportunity to respond to the letter to the Editor [1] concerning our paper "Histological findings and lung dust analysis as the basis for occupational disease compensation in asbestos-related lung cancer in Germany" [2]. This paper evaluated the value of histological findings and the lung dust analysis for compensation of lung cancer as occupational related. For this purpose, all the data from 2015 including the lung dust analysis from the German Mesothelioma Register [2] had been scientifically evaluated and had been compared to asbestos fiber exposure at work based on fiber years, and to radiological findings. For 68 insured persons the pathological diagnosis was the only way to demonstrate the causal connection between asbestos exposure and their disease. In conclusion, we recommended performing the lung dust analysis as a complementary examination if suitable lung tissue was available. We consider this examination as essential before occupational disease under section 4104 is rejected because exposure does not total 25 fiber years or radiological evaluation does not reveal any bridge findings.
Below we would like to address all points raised by the above-mentioned letter.

1. The lung dust analysis is the quantification of asbestos fibers in the lungs of asbestos-exposed workers. It has a long tradition in establishing a link between exposure and disease [3]. The tissue is digested, the lysate is filtered through a membrane and fibers are counted by light microscopy, phase-contrast or electron microscopy. With energy-dispersive X-ray microanalysis (EDX) the fiber type may be analyzed [4]. It should be mentioned, that for assessing the asbestos fiber burden, a laboratory should be well experienced, have a standardized protocol and established reference values using the same method [4]. In our lab, asbestos bodies and bare asbestos fibers are counted separately as described in the material and method section. Bare asbestos fibers are considered for the histologic diagnosis, especially if the asbestos body count is low. However, as they are not visible in the histologic section, our study focused on the asbestos body count as indicated in the figures.

The electron microscopic evaluation is only done if no or remarkably few asbestos bodies are found under the light microscope, but secondary lung changes like fibrosis, in- 
flammation, putrefaction or autolysis are present, according to the current Helsinki Criteria [5]. This analysis is done only to certainly exclude the presence of significantly increased fiber counts. This data was not given in the manuscript, as it had all been negative.

2. The update of the asbestosis grading criteria [4] did not have any influence on our histologic diagnoses. The diagnosis remained unchanged with both grading schemes. The requirement of an average concentration of at least 2 asbestos bodies $(\mathrm{Abs}) / \mathrm{cm}^{2}$ of lung tissue is not new. It corresponds to the definition of the German Society of Pathology from 1997 [6].

3. Asbestos fibers, including chrysotile/white asbestos have a very long half-life in the human lungs. There is plenty of literature about asbestos-exposed workers supporting this statement [7-13]. All authors do find all types of asbestos in the human lungs long time after exposure cessation.

With the lapse of time following the last exposure, there is a decreasing number of patients in our data, a decreasing number of asbestos bodies as well as a decreasing asbestos exposure with respect to fiber years (Figure 3a [2]). This is indeed best explained by people's age. Examining the detectability of asbestos exposure that dates back to 40-60 years would require an insured person with an asbestos-related disease to reach the age of $80-100$ years. The majority of the investigated collective was 55-80 years old (Figure 1a [2]). Therefore, insureds, who are as old as 80 years of age, with a very high and very early exposure to asbestos are missing in our investigation.

4. Stayner et al. [14] do not provide the data about asbestos deposition and accumulation in the human lungs. They examined the relationship between asbestos exposure and the risk of respiratory diseases and found no evidence of the exposure threshold for asbestosis or for lung cancer. This is easily explained because asbestos exposure on the one hand and asbestos deposition and accumulation in the lungs on the other hand do not necessarily correlate with each other due to the different deposition and clearance rates of dif- ferent asbestos fibers with respect to length, diameter and type $[8,9,13]$.

5. Chrysotile asbestos is not accumulated in the human lungs to the same extent as amphibole is. In order to interpret this as low biopersistence of chrysotile, it is the asbestos industry-born and already contested theory [15] based on rat experiments, that is required. Our view is consistent with the well-known characteristics of asbestos (asbestos in the Ancient Greek Language $\alpha \sigma \beta \varepsilon \sigma \tau o \varsigma$ - imperishable), "rootproof," "extremely resistant." It is an international consensus - and already implemented in the corresponding guidelines - that the histological diagnosis of asbestosis requires the existence of fibrosis plus the demonstration of asbestos bodies or uncoated asbestos fibers [16].

In conclusion, we would like to recommend separating the socio-economic and commercial aspects from the scientific i.e., histopathological data in the "biopersistence debate." For compensation claims, all diagnostic tools should be utilized before occupational disease under section 4104 is rejected.

The German Mesothelioma is supported in part by the Deutsche Gesetzliche Unfallversicherung (DGUV).

\section{Key words:}

Lung cancer, Occupational disease, Compensation, Asbestos bodies, Lung asbestos fiber burden, Lung dust analysis

\section{REFERENCES}

1. Baur X, Belpoggi F, Budnik LT, Casteleyn L, Frank AL, Oliver LC, et al. Letter to the Editor (February 14, 2018) concerning the paper "Histological findings and lung dust analysis as the basis for occupational disease compensation in asbestos-related lung cancer in Germany." Int J Occup Med Environ Health. 2018;31(6):00-00, https://doi.org/10.13075/ ijomeh.1896.01332.

2. Feder IS, Theile A, Tannapfel A. Histological findings and lung dust analysis as the basis for occupational disease compensation in asbestos-related lung cancer in Germany. 
Int J Occup Med Environ Health. 2018;31(3):293-305, https://doi.org/10.13075/ijomeh.1896.01148.

3. Cooke WE. Fibrosis of the lungs due to the inhalation of asbestos dust. Br Med J. 1924;2(3317):140-2, https://doi. org/10.1136/bmj.2.3317.147.

4. Roggli VL, Gibbs AR, Attanoos R, Churg A, Popper H, Cagle P, et al. Pathology of asbestosis: An update of the diagnostic criteria. Report of the Asbestosis Committee of the College of American Pathologists and Pulmonary Pathology Society. Arch Pathol Lab Med. 2010;134(3):462-80, https:// doi.org/10.1043/1543-2165-134.3.462.

5. Wolff H, Vehmas T, Oksa P, Rantanen J, Vainio H. Asbestos, asbestosis, and cancer, the Helsinki criteria for diagnosis and attribution 2014: Recommendations. Scand J Work Environ Health. 2015;41(1):5-15, https://doi.org/10.5271/sjweh.3462.

6. Heitz P. [New definition of minimal asbestosis]. Dtsch Arztebl. 1997;94:975. German.

7. Feder IS, Tischoff I, Theile A, Schmitz I, Merget R, Tannapfel A. The asbestos fibre burden in human lungs: New insights into the chrysotile debate. Eur Respir J. 2017;49(6):1602534, https://doi.org/10.1183/13993003.02534-2016.

8. Churg A. Deposition and clearance of chrysotile asbestos. Ann Occup Hyg. 1994;38(4):625-33, https://doi.org/10.1093/ annhyg/38.4.625.

9. Finkelstein MM, Dufresne A. Inferences on the kinetics of asbestos deposition and clearance among chrysotile miners and millers. Am J Ind Med. 1999;35(4):401-12, https:// doi.org/10.1002/(SICI)1097-0274(199904)35:4<401::AIDAJIM12>3.0.CO;2-4.

10. De Klerk NH, Musk AW, Williams V, Filion PR, Whitaker D, Shilkin KB. Comparison of measures of exposure to asbestos in former crocidolite workers from Wittenoom Gorge, W. Australia. Am J Ind Med. 1996;30(5):579-87, https:// doi.org/10.1002/(SICI)1097-0274(199611)30:5<579::AIDAJIM5 > 3.0.CO;2-O.
11. Everatt RP, Smolianskiene G, Tossavainen A, Cicenas S, Jankauskas R. Occupational asbestos exposure among respiratory cancer patients in Lithuania. Am J Ind Med. 2007;50(6):455-63, https://doi.org/10.1002/ajim.20467.

12. Friedrichs KH, Brockmann M, Fischer M, Wick G. Electron microscopy analysis of mineral fibers in human lung tissue. Am J Ind Med. 1992;22(1):49-58, https://doi.org/10.1002/ ajim.4700220105.

13. Churg A, DePaoli L. Clearance of chrysotile asbestos from human lung. Exp Lung Res. 1988;14(5):567-74, https://doi. org/10.3109/01902148809087829.

14. Stayner L, Smith R, Bailer J, Gilbert S, Steenland K, Dement J, et al. Exposure-response analysis of risk of respiratory disease associated with occupational exposure to chrysotile asbestos. Occup Environ Med. 1997;54(9):646-52, https://doi.org/10.1136/oem.54.9.646.

15. Pezerat H. Chrysotile biopersistence: The misuse of biased studies. Int J Occup Environ Health. 2009;15(1):102-6.

16. Asbestos, asbestosis and cancer: The Helsinki criteria for diagnosis and attribution. Scand J Work Environ Health. 1997;23(4):311-6, https://doi.org/10.5271/sjweh.226.

Inke Sabine Feder, Anja Theile, and Andrea Tannapfel

Ruhr University Bochum, Bochum, Germany Institute for Pathology

Corresponding author: Inke Feder

Ruhr University Bochum Institute for Pathology

Bürkle-de-la-Camp Platz 1

D-44789 Bochum

Germany

(e-mail: Inke.feder@rub.de)

This work is available in Open Access model and licensed under a Creative Commons Attribution-NonCommercial 3.0 Poland License - http://creativecommons.org/ licenses/by-nc/3.0/pl/deed.en. 